\title{
Olfactory mediated interactions between Citrus aurantium, Toxoptera citricida and Lysiphlebus testaceipes
}

\author{
Reetu Bahadoorsingh(1) and Ayub Khan ${ }^{(1)}$ \\ (1)University of the West Indies, Dept. of Life Sciences, St. Augustine, Trinidad. E-mail: reetu.bahadoorsingh@gmail.com, ay_khan@hotmail.com
}

\begin{abstract}
The objective of this study was to establish whether there are olfactory interactions in the Lysiphlebus testaceipes, Toxoptera citricida and Citrus aurantium tritrophic system. The response of male and female L. testaceipes to different odour sources of the host plant $C$. aurantium, the aphid host $T$. citricida and aphidplant complex were investigated using a Y-tube olfactometer. Laboratory experiments were conducted by exposing individually aged male and female $L$. testaceipes to eight different odour treatments. Response of the parasitoids was taken after 15 min exposure to the volatiles from the different odour sources and based on their orientation to the particular chamber. Seventy percent of both male and female L. testaceipes showed high attractivity to aphid infested leaves. There was no significant difference based on age and sex of the parasitoid on their choice of odour. The organic compounds released by these combinations acted as semiochemicals in the tritrophic interactions and it is suggested that insect feeding induced attraction of the parasitoid L. testaceipes.
\end{abstract}

Index terms: volatile compounds, parasitoid-host interaction, tritrophic interactions.

\section{Interação olfativa entre Citrus aurantium, Toxoptera citricida e Lysiphlebus testaceipes}

\begin{abstract}
Resumo - O objetivo deste estudo foi investigar se existe interação olfativa no sistema tritrófico entre Lysiphlebus testaceipes, Toxoptera citricida e Citrus aurantium. A resposta de machos e fêmeas de L. testaceipes a diferentes fontes de odor da planta hospedeira $C$. aurantium, o afideo parasita T. citricida e o complexo afideo-planta foram investigados com um olfatômetro do tipo tubo em Y. Os experimentos de laboratório foram conduzidos, expondo-se machos e fêmeas de L. testaceipes de diferentes idades, individualmente, a oito tratamentos com diferentes fontes de odor. A resposta do parasitóide foi tomada depois de 15 minutos de exposição aos voláteis de diferentes fontes de odor, baseando-se na orientação dos parasitóides a uma câmara particular. Setenta por cento de $L$. testaceipes, machos e fêmeas, exibiram maior atração ao odor das folhas infestadas pelo afídeo. Não houve diferença significativa entre idade e entre sexo do parasitóide na sua escolha do odor. Os compostos orgânicos liberados por estas combinações agiram como semioquímicos na interação tritrófica, o que indica que afídeos, ao se alimentarem das folhas, induzem atração no parasitóide L. testaceipes.
\end{abstract}

Termos para indexação: compostos voláteis, interação parasitóde-hospedeiro, interações tritróficas.

\section{Introduction}

Citrus Tristeza Virus (CTV), a closterovirus which originated in Asia, has been distributed worldwide due to the movement of citrus budwood and plants in the establishment of new citrus varieties (Trimmer et al., 2003).

Studies by Halbert et al. (2004) have shown that Toxoptera citricida Kirkaldy (Hemiptera: Aphididae) is the most efficient vector in transmitting CTV.
T. citricida is slightly larger when compared to other aphid species that feed on citrus. It is usually found in large dark brown populations and their seasonal abundance peaks twice a year, which coincides with periods of new citrus growth (Michaud, 1998; Michaud \& Browning, 1999).

Michaud \& Browning (1999) listed a number of natural enemies that feed on aphid colonies. However, natural enemies from the family Aphididae are the most widespread of all biological control agents 
associated with $T$. citricida. Preference should be given to specific parasitoids that establish not only on crop plants but also on alternate host plants including Lysiphlebus testaceipes (Cresson) (Hymenoptera: Aphidiidae), which causes high T. citricida mortality (Michaud, 1998; Halbert et al., 2004).

Insect parasitoids abilities to forage are controlled by their behavioural responses to environmental stimuli by olfactory means. These semiochemicals play an important role and increase the probability of parasitoid - host interactions (Conti et al., 2004). Long-range odours emanating from the plants or host associated cues and short-range cues from damaged plant parts are used to decrease the area of host searching and increase host contact (Powell et al., 1998). Pare \& Tumlinson (1997) showed through chemical labelling studies that induced compounds are synthesized specifically in response to insect damage. Using wind tunnel flight experiments and GC analysis, Scascighini et al. (2005) showed that chemicals released by insect damaged plants contain critical information to guide the parasitoids in the host selection-location process. Plant alelochemicals from the host food source and food odours have been shown necessary cues in host habitat location (Dicke, 1994a, 1994b). The amount of plant volatiles released is dependant on the degree of infestation and the age of the leaves (Takabayashi et al., 1991, 1994; Meiners et al., 2005). Female parasitoids of Lysiphlebus japonica (Ashmead) (Hymenoptera: Aphidiidae) were strongly attracted to the odours from the cotton aphids and their plant hosts. Damaged leaves were more attractive than intact ones and long range cues from the host food source, host associated organisms or the host itself is responsible for guiding the parasitoid to a host habitat (Hou et al., 1996).

The objective of this work was to establish whether there are olfactory interactions in the L. testaceipes, T. citricida and Citrus aurantium L. (Rutaceae) tritrophic system, as well as to investigate the olfactory orientation, combination of odour sources and age responsiveness of male and female $L$. testaceipes to its host, $T$. citricida and its host plant $C$. aurantium.

\section{Material and Methods}

\section{Insect collection}

Samples of parasitized Toxoptera citricida were weekly taken from the field and Lysiphlebus testaceipes allowed to emerge. Newly emerged L. testaceipes wasps were referred to as one-day-old. Male and female L. testaceipes were isolated at oneday-old and placed in separate cages containing damp cotton and honey as a food source to age as either two or three-day-old individuals. The temperature was kept between $29 \pm 1^{\circ} \mathrm{C}$.

\section{Y-tube olfactometer experiments}

A Y-tube olfactometer was used to conduct the bioassays and assess the behaviour and responses of L. testaceipes to different sources of odours. The technique involved in the use of this apparatus is equally to attract the insects towards odour sources so that the insects can respond to the more attractive odour accordingly. The olfactometer consisted of the basic components described by Buitenhuis et al. (2005), with some modifications.

The Y-tube olfactometer had an internal diameter of $2 \mathrm{~cm}$ (both body and arms) and three openings with a birfurcation angle of $110^{\circ}$. The olfactometer was kept in uniform light to avoid unequal attraction. Airflow of $0.5 \mathrm{~m} \mathrm{~s}^{-1}$ was supplied by a vacuum pump attached to the base of the olfactometer and regulated by a flow meter. Bait flasks containing the odour sources were connected to the two arms of the olfactometer by $25 \mathrm{~cm}$ long polyethylene tubing. Activated charcoal filters purified air passing through the odour sources prior to entering each arm of the olfactometer. A parasitoid introduction chamber with a filter at its base was attached to the base of the olfactometer.

\section{Evaluation of treatments}

Each treatment was conducted using one, two and three-day-old $L$. testaceipes. The parasitoid was placed into the olfactometer by the introduction chamber. Males and females were introduced singly into the olfactometer and allowed 15 min to make a choice, since this was the average time required as determined from preliminary trials. Individuals were discarded if no choice was made after this period. A choice was considered made when the parasitoid entered one of the arms of the olfactometer and continued further into the selected column. Two replications for each male and each female were performed using a total of ten males and ten females. For each replicate the odour treatments in each arm were exchanged to balance and remove any possible influence of uneven light. The treatments were changed after five replicates to prevent any contamination by the 
parasitoid reaching the target during the test. The olfactometer was thoroughly washed with acetone and dried after each replication and test.

\section{Odour sources}

Treatment combinations were used as odour sources to conduct the bioassays: 1) undamaged citrus leaves vs. blank (no bait); 2) T. citricida infested leaves vs. blank; 3) T. citricida vs. blank; 4) T. citricida infested leaves vs. uninfested leaves; 5) T. citricida vs. uninfested leaves; 6) T. citricida infested leaves vs. aphids and uninfested leaves; 7) honeydew (on filter paper) vs. filter paper; 8) uninfested leaves from infested citrus tree vs. T. citricida infested leaves.

\section{Data analysis}

The results of the olfactometer experiment were analysed using an $\chi^{2}$ test and binary logistic regression analysis, age and sex. All data were analysed using MiniTab Release 14 Program.

\section{Results and Discussion}

Chi-square tests performed on the results obtained using aged male and female Lysiphlebus testaceipes indicated that age did not influence their behavioural responses to the eight treatments $\left(\chi^{2}=4.892, \mathrm{df}=7\right.$, $\mathrm{p}=0.673)$. The percentage response at one, two and three-day-old individuals was not significantly different from each other.

Binary logistic regression analysis also indicated that age did not have an influence on the decision made by the parasitoids because there was no correlation between the lower and upper limit values of the confidence interval with values of 0.72 and 1.18 , respectively $(\mathrm{p}=0.95)$. Chi-square tests indicated that sex of $L$. testaceipes did not significantly influence their particular preference for the odour treatments (Males: $\chi^{2}=10.139, \mathrm{df}=14, \mathrm{p}=0.752$; Females: $\left.\chi^{2}=10.458, \mathrm{df}=14, \mathrm{p}=0.752\right)$. The results from binary regression also indicated that there was no correlation in the data with respect to sex ratio based on lower and upper limit values ( 0.62 and 1.37 , respectively). Since the initial results showed that age was not a determining factor in the responses of parasitoids, one, two and three-day-old individuals were collectively grouped. These results are in agreement with that of Amalin et al. (2005) who showed that the response to odours may change when parasitoids get older.

The percentage responses of males and females suggested that neither had achieved increasingly significant responses to the treatments. There was an approximate 1:1 ratio between them which suggested even distribution of choice (Table 1). It can be inferred that when the females responded for the purpose of oviposition, the males responded for the purpose of locating the females. Both males and females showed similar but a high degree of response to treatment 2 (host aphid $x$ host plant interaction). This had the greatest attraction for the parasitoids with $80 \%$ of the females and $60 \%$ of the males and a combined response of male and female of $70 \%$ choosing Toxoptera citricida infested leaves as compared with the undamaged citrus leaves or aphids separately giving combined responses of 48.3 and $46.7 \%$, respectively (Table 2). A similar trend was also found by Molck \& Wyss (2003) who tested the odour preference of Aphelinus abdominalis Dalman (Hymenoptera: Aphelinidae) and found that it showed higher responsiveness to the plant-aphid complex than the plant and aphids separately.

A combined $51.7 \%$ of $L$. testaceipes male and female wasps responded to treatment 8 . The volatiles emitted by this particular treatment are also an important chemical cue, since it is from these volatile organic compounds that a plant signals distress and allows the

Table 1. Percentage $( \pm S E M)$ response by male and female Lysiphlebus testaceipes exposed to different odour sources ${ }^{(1)}$.

\begin{tabular}{|c|c|c|}
\hline \multirow[t]{2}{*}{ Odour source } & \multicolumn{2}{|c|}{ Response (\%) } \\
\hline & Male & Female \\
\hline 1. Undamaged citrus leaves vs. blank & $53.3 \pm 12.0$ & $43.3 \pm 17.6$ \\
\hline 2. T. citricida infested leaves vs. blank & $60.0 \pm 20.0$ & $80.0 \pm 5.8$ \\
\hline 3. T. citricida vs. blank & $43.3 \pm 12.0$ & $50.0 \pm 5.8$ \\
\hline 4. T. citricida infested leaves vs. uninfested leaves & $36.6 \pm 3.3$ & $26.7 \pm 3.3$ \\
\hline 5. T. citricida vs. uninfested leaves & $50.0 \pm 5.8$ & $56.7 \pm 3.3$ \\
\hline $\begin{array}{l}\text { 6. T. citricida infested leaves vs. aphids and } \\
\text { uninfested leaves }\end{array}$ & $56.7 \pm 8.8$ & $36.7 \pm 8.8$ \\
\hline 7. Honeydew vs. blank & $33.3 \pm 6.7$ & $56.7 \pm 8.8$ \\
\hline $\begin{array}{l}\text { 8. Uninfested leaves from infested citrus tree vs. } \\
\text { T. citricida infested leaves }\end{array}$ & $50.0 \pm 5.8$ & $53.3 \pm 17.6$ \\
\hline
\end{tabular}

Table 2. Percentage ( \pm SEM) response of combined male and female Lysiphlebus testaceipes exposed to different odour sources $^{(1)}$.

\begin{tabular}{lc}
\hline Odour source & Response (\%) \\
\hline 1. Undamaged citrus leaves vs. blank & $48.3 \pm 9.8 \mathrm{a}$ \\
2. T. citricida infested leaves vs. blank & $70.0 \pm 10.3 \mathrm{a}$ \\
3. T. citricida vs. Blank & $46.7 \pm 6.1 \mathrm{a}$ \\
4. $T$. citricida infested leaves vs. uninfested leaves & $31.7 \pm 3.1 \mathrm{~b}$ \\
5. T. citricida vs. uninfested leaves & $53.3 \pm 3.3 \mathrm{a}$ \\
6. T. citricida infested leaves vs. aphids and uninfested leaves & $46.7 \pm 7.1 \mathrm{a}$ \\
7. Honeydew vs. blank & $45.0 \pm 7.2 \mathrm{a}$ \\
8. Uninfested leaves from infested citrus tree vs. T. citricida & \\
infested leaves & $51.7 \pm 8.3 \mathrm{a}$ \\
\hline (1) Means followed by the same letter along the column are not \\
significantly different ( $<<0.05)$ from each other using $\chi^{2}$ test.
\end{tabular}

(1) Means followed by the same letter along the column are not significantly different $(\mathrm{p}<0.05)$ from each other using $\chi^{2}$ test. 
parasitoid to detect host presence and to locate its hosts from a distance (long range cue). Treatment 8 demonstrated the 'mobile inducer system' of Pare \& Tumlinson (1996), since the citrus leaves on the plant had become infested and physiological changes occurred within the plant allowing the synthesis of induced compounds thus signalling insect damage. This release of compounds increases the searching capability and limits the search area of the parasitoid. Both male and female response of 50 and $53.3 \%$, respectively, showing that there was no significant difference in choice concerning sex (Table 1).

The common factor in the odour sources discussed was the $T$. citricida infested citrus leaves. This suggested that an attractant is present in the leaves from an infested plant as opposed to an uninfested plant. This can be observed with a $48.3 \%$ response to an uninfested plant. Zhang et al. (1998) also concluded that an effective attractant for Lysiphlebus fabarum (Marshall) (Hymenoptera:Braconidae) may have been emitted from plant host interactions. The treatment of T. citricida alone did not show any significant difference $\left(\chi^{2}=2.601\right.$, $\mathrm{df}=1$ ) as an attractant for $L$. testaceipes wasps as only $46.7 \%$ of the wasps responded to the odour of the host alone indicating little preference for the host odour by the parasitoids. Du et al. (1996) observed similar behavioural responses by the aphid parasitoid Aphidius ervi Haliday (Hymenoptera: Aphidiidae) where there was a weak response to the host aphids in the absence of the plant. The response of $46.7 \%$ from treatment 3 (Table 2) suggests that the odour stream is much less important to $L$. testaceipes as a flight orientation cue as compared to the plant host emission.

The results obtained from the bioassay using honeydew collected from $T$. citricida suggested that $L$. testaceipes was not significantly $\left(\chi^{2}=1.167, \mathrm{df}=1\right)$ attracted to honeydew as only $45 \%$ of both male and females responded to this treatment (Table 2). However, Zhu et al. (2005) found that host modified products can act as attractants for parasitoids. A possible reason for the failure was that they used the odour as a chemical cue for food location instead of host location. Although aphid volatiles would have been present in the honeydew, this may still be insufficient to elicit a response from L. testaceipes (46.7\%) since odours from the herbivore alone are too weak (Scascighini et al., 2005).

Learnt behaviour in $L$. testaceipes in this experiment was defined as the same wasp choosing the same arm of the olfactometer after the odour chambers were switched and despite their preference. Chi-square tests using the results in Table 3 established that learnt
Table 3. Double visit response ( \pm SEM) by male and female Lysiphlebus testaceipes (combined) exposed to different odour sources ${ }^{(1)}$.

\begin{tabular}{lc}
\hline Odour source & Response (\%) \\
\hline 1. Undamaged citrus leaves vs. blank & $37.0 \pm 8.7 \mathrm{a}$ \\
2. T. citricida infested leaves vs. blank & $43.0 \pm 1.7 \mathrm{a}$ \\
3. T. citricida vs. blank & $43.0 \pm 4.8 \mathrm{a}$ \\
4. T. citricida infested leaves vs. uninfested leaves & $50.0 \pm 4.2 \mathrm{a}$ \\
5. T. citricida vs. uninfested leaves & $34.0 \pm 6.1 \mathrm{~b}$ \\
6. T. citricida infested leaves vs. aphids and uninfested leaves & $50.0 \pm 3.3 \mathrm{a}$ \\
7. Honeydew vs. blank & $42.0 \pm 3.7 \mathrm{a}$ \\
8. Uninfested leaves from infested citrus tree vs. T. citricida & \\
infested leaves & $37.0 \pm 6.5 \mathrm{a}$ \\
\hline
\end{tabular}

(1)Means followed by the same letter along the column are not significantly different $(\mathrm{p}<0.05)$ from each other using $\chi^{2}$ test.

behaviour was influenced by treatment $\left(\chi^{2}=8.992\right.$, $\mathrm{df}=1, \mathrm{p}<0.05)$. L. testaceipes was capable of associative learning since the parasitoids were reared under laboratory conditions and surrounded by its plant host complex. T. citricida infested leaves and T. citricida were the common factors which determined the associative learning behaviour. The chemical legacy hypothesis of Rietdorf \& Steidle (2002) lends support to the results obtained because L. testaceipes was reared in the laboratory and upon emergence, they were surrounded by only volatiles that were emitted from the mummified host and host plant complex and not a blend of volatiles as would occur in natural environment.

\section{Conclusions}

1. Aphid infested citrus leaves attract $70 \%$ of male and female Lysiphlebus testaceipes.

2. Aphid feeding on citrus leaves induces attraction of the parasitoid L. testaceipes.

\section{References}

AMALIN, D.M.; PENA, J.E.; DUNCAN, R.E. Effects of host age, female parasitoid age and host plant on parasitism of Ceratogramma etiennei (Hymenoptera: Trichogrammatidae). Florida Entomologist, v.88, p.77-82, 2005.

BUITENHUIS, R.; VET, L.E.M.; BOIVIN, G.; BRODEUR, J. Foraging behaviour at the fourth trophic level: a comparative study of host location in aphid hyperparasitoids. Entomologia Experimentalis et Applicata, v.114, p.107-117, 2005.

CONTI, E.; SALERNO, G.; BIN, F.; VINSON, S.B. The role of host semiochemicals in parasitoid specificity: a case study with Trissolcus brochymenae and Trissolcus simony on pentatomid bugs. Biological Control, v.29, p.435-444, 2004.

DICKE, M. Local and systemic production of volatile herbivoreinduced terpernoids: their role in plant-carnivore mutualism. Journal of Plant Physiology, v.143, p.465-472, 1994 b. 
DICKE, M. Why do plants 'talk’? Chemoecology, v.5, p.159-165, 1994a.

DU, Y.J.; POPPY, G.M.; POWELL, W. Relative importance of semiochemicals from the first and second trophic level in host foraging behaviour of Aphidius ervi. Journal of Chemical Ecology, v.22, p.1591-1605, 1996.

HALBERT, S.E.; GENC, H.; CEVIK, B.; BROWN, L.G.; ROSALES, I.M.; MANJUNATH, K.L.; POMERINKE, M.; DAVISON, D.A.; LEE, R.F.; NIBLETT, C.L. Distribution and characterization of Citrus Tristeza Virus in South Florida following establishment of Toxoptera citricida. Plant Disease, v.88, p.935-941, 2004.

HOU, Z.Y.; YAN, F.; CHEN, X. Olfactory responses of Lysiphlebia japonica to volatile chemicals and fresh leaves of the host plants of cotton aphids in olfactometer. Entomologia Sinica, v.3, p.49-57, 1996.

MEINERS, T.; HACKER, N.K.; ANDERSON, P.; HILKER, M. Response of the elm leaf beetle to host plants induced by oviposition and feeding: the infestation rate matters. Entomologia Experimentalis et Applicata, v.115, p.171-177, 2005.

MICHAUD, J.P. A review of the literature on Toxoptera citricida (Kirkaldy) (Homoptera: Aphididae). Florida Entomologist, v.81, p.37-61, 1998.

MICHAUD, J.P.; BROWNING, H.W. Seasonal abundance of the brown citrus aphid, Toxoptera citricida (Homoptera: Aphididae) and its natural enemies in Puerto Rico. Florida Entomologist, v.82, p.425-447, 1999.

MOLCK, G.; WYSS, U. Effect of aphid-infested plants on the host location and learning behaviour of the parasitoid Aphelinus abdominalis. Communications in Agricultural and Applied Biological Sciences, v.68, p.167-177, 2003.

PARE, P.W.; TUMLINSON, J.H. De novo biosynthesis of volatiles induced by insect herbivory in cotton plants. Plant Physiology, v.114, p.1161-1167, 1997.
PARE, P.W.; TUMLINSON, J.H. Plant volatile signals in response to herbivore feeding. Florida Entomologist, v.79, p.93-103, 1996. POWELL, W.; PENNACCHIO, F.; POPPY, G.M.; TREMBLAY, E. Strategies involved in the location of hosts by the parasitoid Aphidius ervi Haliday (Hymenoptera: Braconidae). Biological Control, v.11, p.104-112, 1998.

RIETDORF, K.; STEIDLE, J.L.M. Was Hopkins right? Influence of larval and early adult experience on the olfactory response in the granary weevil Sitophilus granarius (Coleoptera: Curculionidae). Physiological Entomology, v.27, p.223-227, 2002.

SCASCIGHINI, N.; MATTIACCI, L.; D’ALESSANDRO, M.; HERN, A.; ROTT, A.S.; DORN, S. New insights in analysing parasitoid attracting synomones: early volatile emission and use of stir bar sorptive extraction. Chemoecology, v.15, p.97-104, 2005.

TAKABAYASHI, J.; DICKE, M.; POSTHUMUS, M.A. Variation in composition of predator-attracting allelochemicals emitted by herbivore-infested plants: relative influence of plant and herbivore. Chemoecology, v.2, p.1-6, 1991.

TAKABAYASHI, J.; DICKE, M.; TAKAHASHI, S.; POSTHUMUS, M.A.; VAN BEEK, T.A. Leaf age affects composition of herbivore-induced synomones and attraction of predatory mites. Journal of Chemical Ecology, v.20, p.373-386, 1994.

TRIMMER, L.W.; GARNSEY, S.M.; BROADBENT, P. Diseases of Citrus. In: PLOETZ, R.C. (Ed.). Diseases of tropical fruit crops. Wallingford: CABI Publishing, 2003. p.163-195.

ZHANG, Y.; GUO, B.; HOU, Z.; CHEN, X.; YAN, F. Olfactory orientation of the parasitoid wasp Lysiphlebus fabarum to its host food plants. Entomologia Sinica, v.5, p.74-82, 1998.

ZHU, J.; OBRYCKI, J.J.; OCHIENG, S.A.; BAKER, T.C.; PICKETT, J.A.; SMILEY, D. Attraction of two lacewing species to volatiles produced by host plants and aphid prey. Naturwissenschaften, v.92, p.277-281, 2005.

Received on February 2, 2006 and accepted on August 24, 2006 